\title{
Effects of Aluminium Microparticles and Surface Treatment of AlCu4Mg on Mechanical Properties of Adhesive Bond Strength
}

Miroslav Müller

Faculty of Engineering, Czech University of Life Sciences Prague. Czech Republic. E-mail: muller@tf.czu.cz

The aim of the research was to evaluate the lapping length, the adhesive bonded surface treatment and the influence of the filler in the form of the aluminium microparticles on the adhesive bond strength. The alloy AlCu4Mg was the adhesive bonded material bonded by means of a two-component epoxy adhesive used in construction of machines. The filler in a form of aluminium microparticles was added into the adhesive. Laboratory experiments were performed on normalized testing samples of alloy AlCu4Mg prepared under standard ČSN EN 1465 . Within the research three various treatments of the adhesive bonded surface were evaluated, i.e. without the surface treatment (WT), mechanical treatment of the surface (MT) and mechanical and chemical treatment of the surface (MCHT). The adhesive bonds without the adhesive bonded surface treatment (marked as WT) reach the smallest adhesive bond strength. When adding the filler in the form of aluminium microparticles (10 vol. \%) the adhesive bond strength was increased of about $12 \%$.

Keywords: adhesive bonding technology, aluminium alloy, lapping length, surface treatment, microparticles aluminium

\section{Acknowledgement}

This paper has been done when solving the grant IGA TF

\section{References}

[1] MICHNA, S., NÁPRSTKOVÁ, N., KLIMECKA-TATAR, D. (2015). Research the causes of surface stains after eloxal coating for the profile from the AlMgSi alloy using substrucrural analysis. In: Manufacturing Technology, Vol. 15, No. 4, pp. 620-624.

[2] MICHNA, S., MAJRICH, P. (2012). Possible ways of obtaining an aluminium allay by non-traditional waste processing of aluminium beverage containers. In: Manufacturing Technology, Vol. 12, No. 13, pp. 169-174.

[3] HRICOVA, J., NÁPRSTKOVÁ, N. (2015). Surface roughness optimization in milling aluminium alloy by using the Taguchis design of experiment. In: Manufacturing Technology, Vol. 15, No. 4, pp. 541-546.

[4] PEREIRA, J.M., FERREIRA, F.V., ANTUNES, P.J., BÁRTOLO A.M. (2010). Analysis of manufacturing parameters on the shear strength of aluminium adhesive single-lap joints. In: Journal of Materials Processing Technology. Vol. 210, pp. 610-617.

[5] MÜLLER, M. (2015). Research on surface treatment of alloy AlCu4Mg adhesive bonded with structural singlecomponent epoxy adhesives. In: Manufacturing Technology, Vol. 15, No. 4, pp. 629-633.

[6] MÜLLER, M., HERÁK, D. (2010). Dimensioning of the bonded lap point. In: Research in Agricultural Engineering. Vol. 56, No. 2, pp. 59-68.

[7] MÜLLER, M., VALÁŠEK, P. (2013). Comparison of variables influence on adhesive bonds strength calculations. In: Manufacturing Technology, Vol. 13, No. 2, pp. 205-210.

[8] HERÁK, D., MÜLLER, M., DAJBYCH, O., SIMANJUNTAK, S. (2009). Bearing capacity and corrosion weight losses of the bonded metal joints in the conditions of Indonesia, North Sumatra province. In: Research in Agricultural Engineering, Vol. 55, No. 3, pp. 94-100.

[9] EBNESAJJAD, S., LANDROCK, A.H. (2014). Adhesives Technology Handbook, 3rd edition, William Andrew, $432 \mathrm{p}$.

[10] MESSLER, R., W. (2004). Joining of materials and structures from pragmatic process to enabling technology. Burlington: Elsevier, 816 pp.

[11] RUGGIERO, A., VALÁŠEK, P., MEROLA, M. (2015). Friction and wear behaviors of Al/Epoxy Composites during Reciprocating Sliding tests. In: Manufacturing technology, Vol. 15, No. 4, pp. 684-689.

[12] BOCKENHEIMER, C., VALESKE, B., POSSART, W. (2002). Network structure in epoxy aluminium bonds after mechanical treatment. In: International Journal of Adhesion \& Adhesives, Vol. 22, pp. 349-356.

[13] RUDAWSKA, A. (2014). Selected aspects of the effect of mechanical treatment on surface roughness and adhesive joint strength of steel sheets. In: International Journal of Adhesion and Adhesives, Vol. 50, pp. 235-243. 
[14] HARRIS, A.F., BEEVERS, A. (1999). The efects of grit-blasting on surface properties for adhesion. In: International Journal of Adhesion \& Adhesives, Vol. 19, pp. 445-452.

[15] ELBINGA, F., ANAGREHB, N., DORNA, L., ULMANNA, E. (1999). Dry ice blastingas pretreatment of aluminum surfaces to improve the adhesive strength of aluminium bonding joints. In: International Journal of Adhesion \& Adhesives, Vol. 23 pp. 69-79.

[16] LUNDER, O. LAPIQUE, B., JOHNSEN, K., NISANCIOGLU K. (2004). Effect of pre-treatment on the durability of epoxy-bonded AA6060 aluminium joints. In: International Journal of Adhesion \& Adhesives, Vol. 24, pp. 107117.

[17] BJORGUM, A. LAPIQUE, F., WALMSLEY, J., REDFORD K. (2003). Anodising as pre-treatment for structural bonding. In: International Journal of Adhesion \& Adhesives, Vol. 23, pp. 401-412.

[18] GALUSEK, D., SEDLÁČEK, J., RIEDEL, R. (2007). Al2O3-SiC composites prepared by warm pressing and sintering of an organosilicon polymer-coated alumina powder. In: Journal of the European Ceramic Society, Vol. 27, No. 6, pp. 2385-2392.

[19] KIM, H. S., KHAMIS, M. A. (2001). Fracture and impact behaviours of hollow micro-sphere/epoxy resin composites. In: Composites Part A: Applied Science and Manufacturing, Vol. 32, No. 9, pp. 1311-1317.

[20] AGOUdJIL, B., IBOS L., MAJESTÉ, J. C., CANDAU, Y., MAMUNYA, YE. P. (2008). Correlation between transport properties of Ethylene Vinyl Acetate/glass, silver-coated glass spheres composites. In: Composites Part A: Applied Science and Manufacturing, Vol. 39, No. 2, pp. 342-35.

[21] SHAO-YUN FU, XI-QIAO FENG, BEMD LUKE, YIU-WING MAI, (2008). Effects of particle size, particle/matrix interface adhesion and particle loading on mechanical properties of particulate-polymer composites. In: Composites: Part B, Vol. 39, pp. 933-961.

[22] RAMAZAN, K., MEHMET, S., BEKIR, Y. (2008). Influence of adhesive thickness and filler content on the mechanical performance of aluminium single-lap joints bonded with aluminium powder filled epoxy adhesive. In: Journal of materials processing technology, Vol. 205. Pp. 183-189.

[23] MÜlLER, M., CIDLINA, J., DĚDIČOVÁ, K., KROFOVÁ, A. (2015). Mechanical properties of polymeric composite based on aluminium microparticles. In: Manufacturing Technology, Vol. 15, No. 4, pp. 624-628.

[24] VALÁŠEK, P. (2014). Mechanical properties of epoxy resins filled with waste rubber powder. In: Manufacturing Technology, Vol. 14, No. 4, pp. 632-637.

[25] VALÁŠEK, P. (2015). Polymeric microparticles composites with waste EPDM rubber powder. In: Agronomy Research, Vol. 13, No. 3, pp. 723-731.

[26] TAMAI, Y., ARATANIC, K., (1972). Experimental study of the relation between contact angle and surface roughness. In: The Journal of Physical Chemistry. Vol. 22, pp. 3267-3271.

[27] PEREIRA, J.M., FERREIRA, F.V., ANTUNES, P.J., BÁRTOLO A.M. (2010). Analysis of manufacturing parameters on the shear strength of aluminium adhesive single-lap joints. In: Journal of Materials Processing Technology. Vol. 210, pp. 610-617.

[28] CHO, J., JOSHI, M.S., SUN, C.T. (2006). Effect of inclusion size on mechanical properties of polymeric composites with micro and nano particles. In: Composites Science and Technology. Vol. 66, pp. 1941-1952. 